\title{
THE DEUELOPMENT OF ISLAMIC ENGLISH REGISTER IN PAWENING MADRASSA
}

\author{
'FAIZAL RISDIANTO, ${ }^{2}$ MUKHAMADI \\ IIAIN SALATIGA, 2SMK Batik 2 Surakarta \\ jopr@iainsalatiga.ac.id
}

\begin{abstract}
This research is descriptive qualitative and has three research objectives: to know the forms of Islamic English Registers, Islamic English Register characteristics, and the boosting force and impeding factors of the development of the Islamic English Register at Pawening Madrassa (PM), Surakarta, Indonesia. From the results of observations and interviews, it can be seen the results of the study as follows: There was a direct learning strategy using Teacher-Centered-Approach and the "Army-Method" learning model. The Students' learning model follows a Behaviorist pattern that focused on the habituation of language skills with a pattern of creating the habit of Students with a Punishment and Reward pattern. The boosting Force of the Learning Process of Islamic English Register at PM were adequate facilities, infrastructure, language learning Environment to develop Students to be able to speak and write in the Islamic English Register whereas, the impeding factor was the attitude of Students who consider trivial the given penalties of their dishonored actions. This research can be a good exemplary of the development of Islamic English Register in Islamic Boarding School.
\end{abstract}

Keywords: Register, Islamic English, Direct method, Army method, TeacherCentered-Approach

\section{INTRODUCTION}

Register points out to the variations of language that reflect changes caused by various factors of conditions such as change of speech partners, the background of situations, and the topic of conversation. Registers are also explained as particular lexical and grammatical choices spoken by communicators depending on the situational context, participants in the conversation, and the function of language in discourse(Holmes, 1992), (Atiek Mustikawati, 2015) (Clark \& Yallop, 2006)(Miji Lestari, 2012).

One instance of a very interesting use of the Register to be studied and scrutinized is the Register in the programs of Tablighi Jamaat madrassa. Tablighi Jamaat is an international Islamic missionary organization founded in 1926 by Syaikh Ilyas in India. The group moves from the lower class, then invites the entire Muslim group regardless of social and economic levels in getting closer to the Islamic instruction as brought by the Prophet Muhammad PBUH . 
In less than two decades, the Tablighi Jamaat was successful in South Asia. Led by Maulana Yusuf, the son of Maulana Ilyas as the second figure, the organization began to develop its programs in 1946, and within 20 years, its spread had reached Southwest Asia and Southeast Asia, Africa, Europe, and North America (Kuiper, n.d.), (Reetz, n.d.). In Indonesia, with the development of Tablighi Jamaat although not as popular as group movements such as Muhammadiyah or Nahdlatul Ulema, the Tablighi Jamaah has an enormous number of members. Members of Tablighi Jamaat in Indonesia vary greatly, ranging from artists to the army, professionals, and others. The center of Tabligh worshipers in Indonesia is in Jakarta, especially in the Kebon Jeruk Masjid (Rusdiana, 2016). This is the central mosque all over Indonesia while for the scope of Islamic Madrassa within the great influence of Tablighi Jamaat activists, there are several Islamic boarding schools, one of them is Tablighi Jamaat Pawening Madrassa (PM), Central Java. It is an Islamic Propagation Madrassa that particularly prepares offsprings of religious preachers who also master general knowledge including foreign language skills namely Islamic English (Kuiper, n.d.) .

In Addition, dealing with the phenomenon of English which continues to grow to be the number one international language that encourages each nation to promote learning and mastery for the fulfillment of the political, economic, social and cultural needs of the nation in the midst of the association of the world group and to a lesser extent, at the level of group groups and individuals, the use of English becomes more gigantic and tends to be penetrative of native languages due to globalization and the vastness of the internet network. Particularly, with regard to the history of English use in areas where the majority of the population is Muslim. Rahman (Rahman, n.d.) differentiates three types of attitude, namely resistance and rejection, acceptance and assimilation, and pragmatic use.

English is taken for granted identified with the language of colonialists or also the language of Christian preachers as generally known as first reaction and impression of the Muslims, especially in the colonies, is a reluctance to master it and rejection in its use. Then, on further development, English was also identified with access to power and the economy, some Muslims began to accept and fuse English in several aspects of their lives, especially worldly life. This choice of attitude led to a clear separation in the grouping of Muslims due to the emergence of a middle grade who relied on their English ability to obtain employment and welfare, it was separated from Muslim clerics who for ideological reasons refused English and it also happened on proletarian Muslims who did not have access to English learning and mastery.

Furthermore, when English is realized as a tool for anyone to achieve their goals, many Muslims selectively and tactically utilize English only when English is able to empower them and strengthen their identification as Muslims. This attitude is called pragmatics use which is pioneered by Islamist groups or groups of people who prioritize the interests of Islam (Mahboob, 2009)

In the modern world which condemns the colonization of one nation by another nation and the hegemony of one culture over another, it is the attitude of Muslims towards English that is categorized as pragmatic use that is increasingly spreading globally and 
universally. The emergence of discourse about the positive sides of English now covers the extent to which English is able to represent all kinds of identities intention and objective from each of its users or the extent to which English develops into the property and identification of its users and no longer belongs to and the identification of the native speaker (Mahboob, n.d.).

Not surprisingly, a variety of English languages continue to emerge that are no longer categorized to be deviations from the native English communicators of British English and American English, but it is categorized as native English representing the identities of new communicators such as Indian English, Singaporean English, Pakistani English, etc.

As the identification of the communicators, Pakistani English, has a variety of differences not only in terms of linguistics such as grammar, pronunciation, choice of words, etc., but also in terms of ideology because Pakistani English is burdened with the wishes of the majority of its communicators, Pakistani Muslims, to be able to convey values and the noble teachings of Islam, therefore, English can become the appropriate language for them to communicate all their life experiences as Muslims. Modern Muslims should not reject English, they need to clearly define their needs for English in general and also in detail.

The Endeavors to make English be more appropriate language for expressing the Muslim identification of its communicators have moved Muslim English education practitioners around the world, especially those from areas with a predominantly Muslim population, to gather and discuss it more seriously at an international conference on English and Islam periodically each year in the leading Islamic universities all over the world. This organization has given birth to conceptual terms such as English for Islamic Purposes, Islamization of English, and English as an Islamic Language or even Islamic English (Rahman, 2008), (Marengo et al., 2017),

Indonesia, as the largest Muslim country in the world, will certainly be the most affected, and thus it is also expected to be the most influential in the context of the development of Islamic English Discourse and Register to represent this Muslim identification. How much opportunity does Indonesia have to be more active and more broadly involved in the dynamics of the discourse of interrelation between English and Islam in the life of Muslim communicators certainly depends on the reality to what extent the issues of linking the use of English with the Muslim identification of the speaker are of concern and attitude or concrete actions by stakeholders or groups of people in Indonesia who mobilize all practices of English education in Indonesia (Rusdiana, 2016).

This will become the main agent for the creation of opportunities for English in Indonesia to develop into English that is more suitable for displaying their Indonesian identification with Islam as a source of life values which is guided by the majority of the population. Through this research, the issues surrounding the relationship of English with the daily life of communicators in Indonesia, which are predominantly Muslim, have become clearer so that they can sort out the usefulness and urgency of their attitudes in the practice of English education in Indonesia. 
Based on the description above, the researcher is interested in bringing up the uniqueness of the Register or the use of Islamic English at PM, to be the research objectives. This research is highlighted to find out the forms of Islamic English Registers, Islamic English Register characteristics and the factors that cause the emergence of Islamic English Register at PM, Central Java. Learning strategy is a learning activity that can be carried out by teachers and students so that learning objectives can be achieved effectively and efficiently. Endeavors to implement learning plans that have been prepared in real programs so that the objectives that have been prepared can be achieved optimally, then we need a method used to realize the strategies that have been set

Thus, a learning strategy can happen using several methods. For instance, to implement an expository strategy and the lecture methods can be used as well as Question and Answer method or even discussion by utilizing available resources including using learning media. Therefore, the strategy is different from the method. Strategy shows the planning to achieve a goal, while the method is a way that can be used to implement the strategy. In other words, the strategy is "a plan of operation achieving something", while the method is "a way in achieving something"(Risdianto, 2016).

Approach can be interpreted as a starting point or our perspective on the learning process. The term approach points out to the view about the process that is still very general in nature. Roy Killen (Effective Teaching Strategies: Lessons from Research and Practice - Roy Killen - Google Buku, n.d.) noted that there are two approaches to learning, namely the teacher-centered approach and the student-centered approach. The teachercentered approach decreases direct learning strategies or Direct Instruction, deductive learning, or expository learning. Whereas, student-centered learning approaches decrease inquiry learning strategies and discover and inductive learning.

Related to learning models themselves are usually arranged based on various principles or theories of knowledge. The experts compile a learning model based on the principles of learning, psychological, sociological theories, systems analysis, or other theories that support. Globally, the factors that influence student learning can be divided into three types, namely: Internal factors (factors within the student), namely the physical condition of the student and external factors (factors from outside Students), namely the environmental conditions around Students (Lindblom, 2004) (Kaharuddin, 2019).

The above factors are in many ways often interrelated and influence one another. A student who is conserving science or is extrinsically motivated for instance, usually tends to take a learning approach that is simple and not profound. Conversely, a student with high intelligence (internal factors) and get positive encouragement from his parents (external factors), might choose a learning approach that is concerned with the quality of learning outcomes. So, because of the influence of these factors, high-achievers and under-achievers appear or fail altogether (Risdianto et al., 2019), (Widodo, 2018).

\section{METHOD}

The design of this research is descriptive qualitative. According to Isaac descriptive research is a research that systematically explains the situation and facts of certain 
populations factually and accurately. More than that Arikunto states that the final conclusions in descriptive studies can be in the form of words or sentences, not in the form of numbers. (Suharsimi Arikunto, 1992), (Putri et al., 2018), (Sungatmi, 2019)

Primary data sources are data that is directly accessed by researchers. In this study, the authors take data from observations of English grades at PM. Both teacher and student become very important observation data for this research. Secondary data sources are data that are indirectly used by researchers such as data taken from documents like the curriculum, syllabus and teaching materials (Almurashi et al., 2017).

The researcher uses the method of observation and documents (the results of observations and interviews with teachers and Students) for data collection. In this study, the existence of observation and documentation methods are expected to know the exact learning models of teachers and Students learning models appropriately and accurately. With this method, it is expected that the profile of PM can be explained clearly. To get this important data from the beginning of May 2019 until the end of August 2019, the researchers observed the practice of all English teachers in PM.

\section{FINDINGS AND DISCUSSION}

\section{Analysis of Teacher's Teaching Activity}

In PM, there are five Islamic English Teachers, namely: A, B, C, D, and E. All of the Islamic English Teachers were graduate Students of Islamic madrassa and University. This Madrassa applies Kulliyatul Mu'allimin Islam model. This model or system aims to produce Islamic teaching and propagation staff who are not only mastering Islamic material but also are able to speak and write fluently two foreign languages (Arabic and English). The following will present the results of observations for 10 (ten) times entering Islamic English grades that are taught by the five teachers.

\section{a. Observation Results of Teacher's Activity on June 1, 2019}

The first observed grade was the Islamic English grade in grade Six. This observation was carried out on Saturday night at $8 \mathrm{pm}$ on June 1, 2019. This evening grade is different from other grades because the Environment is more informal. The grade was held in the Islamic boarding school's hall. The evening grade is held after the Students perform the Isha prayer 'and held in a relaxed Environment.

$\mathrm{A}$ as one of the senior instructors at PM has a relaxed profile but at the same time having a strict teaching style. He began the initial learning programs by saying greetings and "Assalamu Alaikum, Good Evening, Khoiriyyat everyone". That night he explained the sub material "Opening and Closing a Conversation in Islamic English". The teaching and learning contained the all-round Opening and Closing a Conversation following formulas and instances of everyday practical sentences. The word Khoiriyyat which means "All is well" is a common usage of Islamic greeting in the group of Pakistani and Indian Moslems. The Students or Islamic boarding school' Students, although sometimes made fun or made fools among friends, remains highlighted and enthusiastic in following the learning and teaching process. 


\section{b. Observation Results of Teacher's Activity on June 15, 2019}

The second observed grade was the Islamic English grade in grade two. This observation was carried out on Saturday morning at 08.50-10.10 on June 15, 2019, in grade 2-C. From this date, researchers were given the chance by PM's headmaster to enter grades ranging from grade One grade Six. The grade is a formal grade like the other grades. Starting grades One to Three are called "Tsanawiyah" while from grades Four to Six are referred to as "Ma'had Aly". For Students whose background is Junior High or Tsanawiyah outside PM should join "Ma'had Aly" which is at the level of " Aliyah" holds a special grade. This is aimed at accommodating those who are not familiar with the Kulliyatul Mu'allimin Islam system in PM Boarding School are likely to be the patterns and systems that have been implemented from grade one.

Islamic English Learning in grade 2-C was taught by B, who is a senior teacher at PM Boarding School. At that moment he elaborated on the life history of Prophet Muhammad PBUH. He did not only describe the glossary of vocabularies Related to Islamic English but he also explained all the goodness and positive sides of Prophet Muhammad PBUH. It is an inspiring lecture boosting Students to imitate the noble character and exemplary of Prophet Muhammad PBUH.

\section{c. Observation Results of Teacher's Activity on July 13, 2019}

The third observed grade was the Islamic English grade in grade three. This observation was done on Saturday morning at 08.00-10.00 a.m in grade 3-C. Islamic English Learning in grade $3-\mathrm{C}$ is taught by the Teacher $\mathrm{C}$.

$\mathrm{He}$ is one of the senior instructors at PM Boarding School. He has a neat appearance by wearing a Muslim's cap and his teaching style can be categorized as strict, disciplined, and very enthusiastic. This can be seen when the teaching began with greeting towards Students with formal Spoken English expressions and expressions of positive motivations the morning with the following narration:

C:"Assalamualaikum warahmatullah!".

Students grade 3-C: "Wa'alaikum salam warahmatullahi wabarakatuh!".

$\mathrm{C}$ : "How are you today?"

Students grade 3-C: "Alhamdulillah, Fine, Thank you".

C: "Are you very well today?".

Students grade 3-C: "Life is wonderful and amazing".

$\mathrm{C}$ : "what is our focus this day?".

Students grade 3-C: "Our focus this day is Ennnnngggglishh"

It is an interesting and unique teaching and learning model. The lesson starts with a passionate sentence "Life is wonderful and amazing". Although researchers have understood the meaning and meaning of the sentence, in other sections it also needs to be cross-checked into Students of Madrassa about what they understand from the sentence. Some of them said that life is beautiful and great. It was a good initial encouragement and stimulus to the Students so that they always have a passion for learning and togetherness by frequently mentioning the expression like "Our focus this day is English". This is some instances of an effective language environment that for years has been practiced PM Boarding School, Central Java. 


\section{d. Observation Results of Teacher's Activity on July 27, 2019}

The fourth observed grade was the Islamic English grade in Grade Six. This observation was carried out on Saturday morning at 07.30-08.10. Islamic English Learning in grade Six is taught by D who like other senior instructors at PM having a neat appearance by wearing a cap and wearing PM batik uniforms. His teaching style is similar to A who is calm but clear in explaining the material. The Islamic English Grade on July 27, 2019 had the sub-material "Allah is the Lord of the universe". This material belongs to Islamic English registers and at the same time is an informative and inspiring material of Islamic teaching on the Oneness of God.

\section{e. Observation Results of Teacher's Activity on 3 August 2019}

The fifth observed grade was the Grammar grade that was taught by E. This Saturday learning on 3 August 2019 is applied in grade 3-TKS. The meaning of the abbreviation of TKS is Takhosus or "Special grade". From the beginning, the researchers thought that the grade labeled "TKS" was a special grade for the brightest student but actually it is not. The grade labeled "TKS" is a special grade for Students whose background are State Junior high School or from the Tsanawiyah level which is not a Kulliyatul Mu'allimin program but wants to continue to the level of Aliyah or Ma'had Ali in PM Madrassa. This meeting on Saturday, August 3, 2019, was hosted by E, a young teacher alumnus of PM. At this meeting on 3 August, 2019 E only supervised and corrected Students who were presenting the material and at the same time gave praise for the correct answer and punished for the wrong answer. It is a unique learning model of the "Punishment and Reward" model was the very close relationship between teacher and student.

After 40 minutes of lessons taking place in grade 3-III TKS, then researchers asked permission from $E$ to take part in observing in the next grade, the sixth observation grade is grade 1-TKS. As for grade 3-TKS belongs to special preparation grade for Students who used to be from State Senior High School or Tsanawiyah outside PM.

\section{f. Observation Results on Teacher Learning August 24, 2019}

The seventh observed grade was Reading 3 grade, which was taught by A. This Saturday learning on August 24, 2019, was implemented in the regular grade 3-B. A as one of the senior instructors at PM has a more relaxed teaching style, He smiles a lot. A began the initial learning programs by saying greetings "Assalamualaykum" and "Good Morning, everyone". That morning he explained the material "Reading-English Lesson 3" with a sub-material entitled "ISLAM". This material although using the book Reading but on that day was more directed to the mastery of vocabulary and the ability to make sentences based on the reading material. There was also additional preaching of A dealing with the importance to learn and totally embrace Islamic teaching.

After 40 minutes of lessons taking place in grade III B, the researcher then asked permission from $A$ to participate in observing the next grade, the eighth observation grade is 3A-grade. As in 3-B grade, A in this grade explained the material of "English ReadingLesson 3" with a sub material titled "THE QURAN". This material on that day was more directed at mastering vocabulary and the ability to make sentences based on the reading material. 
In general, in the observation of researchers after entering eight grades held Islamic English learning in it can be concluded that there a zeal of Islamic revitalization by preaching activity along with the socialization of Islamic English Register. It also used direct learning strategy and using Teacher-Centered-Approach which is highly directed by the teacher. Methods suitable for this strategy and approach include: lecturing and preaching, proposing questions and answers, giving demonstrations, exercises, and drills. This strategy and approach are made clear by the "Army-Method" learning model, which emphasizes high discipline and teacher authority and the direct method

Another interesting observation on the use of Islamic English Register in PM in the teaching activity of five Islamic English teachers in PM, the researcher also made observations on the responses and activeness of Students or Students and the use of Islamic English Register made by Students during the ongoing learning process. The researcher tried to observe not only the activity of the teacher inside and outside the grading room but he also asked questions and discuss with Students about their achievement of the learning process of Islamic English. The following are the observations of researchers on eight grades taught in Islamic English on 1 June 2019, 15 June 2019, 13 July 2019, 27 July 2019, 3 August 2017, and 24 August 2019.

\section{a. Observation Results of Student Learning Model on June 1, 2019}

The first observed grade observed was the Islamic English grade in grade Six. This observation was carried out on Saturday night at 8 pm on June 1, 2019. Today's evening grade is quite different from other grades because the Environment is more informal. The grade was held in the Islamic boarding school's hall. The evening grade is held after the Students perform the Isha 'and Tarawih prayers and are held in a relaxed environment. Students although sometimes made a joke among them, remained highlighted and enthusiastic in the process of learning.

After the completion of the 60-minute learning process, the researcher had the opportunity to have a dialogue with a sixth-grade student named G. He told me how grateful he was to be able to study at the PM Madrassa because compared to his fellow villagers who did not study at Islamic boarding school. He felt grateful for getting a better religious Environment and language learning Environment. Some of his friends in his village were affected by bad deeds and were rebellious and difficult to accept parent's advice. Regarding learning both Islamic English and Arabic he felt the effectiveness of this Direct Method learning model because of the cheerful and joyful Language Environment.

\section{b. Observation Results of Student Learning Model June 15, 2019.}

The second grade observed was the Islamic English grade in the second grade. This observation was carried out on Saturday morning at $08.50-10.10$ on June 15, 2019, in grade 2-C. From this date, researchers were given the opportunity by madrassa headmaster to enter grades ranging from grade I to grade VI. The grade is a formal grade like the other grades. Starting grades, I to III are called "Tsanawiyah" while from grade IV to VI are referred to as "Ma'had Aly".

On June 15, 2019, the teacher explained the sub-material of Prophet Muhammad PBUH ". In its study begins by explaining the all-around history of the life of the Prophet 
Muhammad. The translation of the phrase Salallahu Alaihi wassalam into Peace be Upon Him is clearly explained by the teacher. The Students seemed enthusiastic and highlighted in paying attention to the teaching of the teacher and one interesting thing was the intelligence of the instructor to direct the Students to stay highlighted by being given questions and being corrected immediately if there were any wrong answers.

\section{c. Observation Results of Students Learning Model July 13, 2019}

The third grade observed was the Islamic English grade in the third grade. This observation was carried out on Wednesday morning at 09.30-10.10 in grade III-C. Islamic English Learning in grade $3-\mathrm{C}$ is taught by $\mathrm{C}$ who has a teaching style that can be categorized as strict, disciplined, and very enthusiastic. In the Researcher's Observations, there are some Students who are careless and playful in answering but in general, Students were eager to follow lessons from beginning to end. Maybe because as said by F, Principal of the PM that the success of the instructor at the PM is able to make Students were happy to scream out over and over imitating what the teacher said. So that the Environment of "noise" of learning is not categorized a problem but in general a stimulus so that there is a shared passion to achieve "fluency" or fluency and habits of speaking and writing in a foreign language, in this case, is Islamic English.

\section{d. Observation Results of Students Learning Model 27 July 2019}

The fourth grade observed was the Islamic English grade in sixth grade. This observation was carried out on Saturday morning at 07.30-08.10. Islamic English Learning in grade 4 is taught by D. The Islamic English grade on July 27 has a "Passive voice" submission. This material is explained clearly and Students were guided to make instances based on formulas and instances of Passive voice that have been written on the board. In general, the process of learning and teaching "Grammar" on that day went normally and smoothly.

\section{e. Observation Results of Students Learning Model 3 August 2019}

The seventh grade that was observed was the Grammar grade that was taught by $\mathrm{E}$ This Sunday learning on 3 August 2019 is applied in grade III TKS. The meaning of the abbreviation of TKS is Takhosus or special grade. From the beginning, the researchers thought that the grade labeled "TKS" was a special grade for the brightest children but it was not so. The grade labeled "TKS" is a special grade for Students whose background is a public junior high school or from the Tsanawiyah level which is not a KMI program but wants to continue to the level of Senior High School or Ma'had Ali in the PM Boarding School Central Java.

At this August 3 meeting, E only supervises and corrects Students who are presenting the material and at the same time gives praise for the correct answer and punishes the wrong answer. What is unique and interesting from the learning model of the "Punishment and Reward" model is that the teacher and student relationship patterns are very close. If there is a "Punishment" or "Punishment" in the form of a permanent board markers on the cheeks or the chin of the Students but it did not make a problem but it made laughter to see the Students being punished also friends who see it. A conducive and pleasant 
condition and good environment for the students coming from the outside who want to continue at Ma'had Aly level at PM.

\section{f. Observation Results of the Students Learning Model on August 24, 2019}

The ninth-grade observed was Reading 3 grade, which was taught by Teacher. A. The lesson on Saturday, August 24, 2019, was implemented in the regular grade 3-B. Teacher. Ibrahim began the initial learning programs by saying greetings and "Good Morning, everyone". That morning he explained the material "Reading-English Lesson 3" with a sub-material entitled "ISLAM". This material although using the book Reading, but on that day is more directed at mastering the Islamic English Register material and making sentences based on the discourse. So, in addition to explaining the material briefly, Students are taught to jointly make sentences and paragraphs with the text title "ISLAM". In the observations, although sometimes joking among friends, they remain highlighted and enthusiastic in following the learning and teaching process.

After 40 minutes of lessons taking place in grade III B, the researcher then asked permission from the Teacher. A to participate in observing the next grade, the tenth observation grade is grade 3-A. As in grade 3-B Teacher. Ibrahim in this grade He explained the material "Reading-English Lesson 3" with a sub material titled "THE QURAN". This material on that day was more directed at mastering Islamic English Register material and making sentences based on the discourse.

According to the observations of researchers in the learning on Saturday, August 24, 2019, which was implemented in regular grades 3A and 3B by A, it can be stated that after the Students had gained mastery of Vocabulary or sufficient vocabulary in the first and second years then starting in the third year then they learn English Grammar or Islamic English Grammar and also begin to be introduced to Genres of texts in Islamic English. Hesitation Removal or the elimination of doubt in learning is already running. The Receptive Process or Language Acquisition has been running effectively and has only been taught the Productive process in foreign language skills or skills.

\section{Boosting aspect of Islamic English Learning Process at PM}

The boosting aspects of Islamic English Learning Processes at PM Boarding School is the existence of facilities, infrastructure and language environment that are sufficient to encourage and develop students to be able to speak and write in Islamic English.

Two supporting programs other than in the grade that was successfully observed by the researcher are Speech training programs for all Students and Vocabulary Mastery Drill after having lunch. This is a supporting element of the activity which is quite effective in realizing step by step of Foreign Language Acquisition, in this case, is Islamic English.

\section{a. Students Speech Training Programs}

Speech training programs for all Students except Students in grades 5 and 6. This activity is weekly and this is a supporting element of the activity which is quite effective in realizing step by step Language Acquisition, in this case, is Islamic English. On Sunday, August 4, 2019, researchers had the opportunity to make observations on the programs of Students giving a speech. It is interesting to see Students from grades one through four directed by their mentors not from their daily teachers who used to teach 
Islamic English but it was taken from their seniors who were in grades 5 and 6 . The regeneration from senior to junior in PM is quite effective in arousing Students to be confident and have the courage to make speeches in Islamic English even though they are still in the form of simple speeches.

\section{b. Vocabulary Mastery Drill}

Vocabulary Mastery Drill activity for all Students except Students in grades 5 and 6. This activity is weekly and this is a supporting element of the activity which is quite effective in realizing the stages of Language Acquisition. In PM has long been a policy of Headmaster of the school so that after two weeks Arabic Weeks speaking exercise then, after that one-week English Week speaking exercise and fortunately on Saturday, July 20, 2019, the researcher had the opportunity to observe the Drill Mastery Vocabulary in the Islamic Boarding School.

\section{Impeding Aspect in the Process of Learning English in PM}

The main impeding factor in the Learning Process of Islamic English in PM is the attitude of Students who categorized trial all the punishment from teachers. There is concern from the headmaster of the Madrassa that if the punishment is of a physical punishment such as being hit it will potentially make Students feel resentful towards the instructor or senior who gave the punishment.

There was a kind of punishment to build Students' discipline as it is now like being instructed to stand in the hot mid-day from morning until afternoon. They were instructed to stand in a hot morning and afternoon to say for 5-10 minutes of repetitive sentences like:" Hey, Boys, speak English! Hey, Boys, speak English! Another punished student was given a necklace made of cardboard that reads LET'S SPEAK ENGLISH but unluckily, it did not give a profound or deep impact to Students. They consider these penalties trivial and normal.

\section{CONCLUSION}

Referring to the three things that have been explained and explained earlier about the Islamic revitalization, the development of Islamic English Register, the teacher learning model, the Students learning model and the boosting and impeding aspects in the process of learning Islamic English in the PM that can be concluded as follows:

In general, in the observation of researchers after entering ten grades held Islamic English learning in it can be concluded that there a zeal of Islamic revitalization, the socialization of Islamic English register by the use of direct learning strategy and using Teacher-Centered-Approach. According to the researchers' observations, the student learning model in PM adheres to a Behavioristic pattern that emphasizes habitual skills and language skills with an Army method pattern that controls and build Students' character s by the use of Punishment and Reward pattern. Praise and appreciation for those who succeed and educative punishment for those who fail in the learning process.

The boosting aspect of Islamic English Learning Processes at PM is the existence of facilities, infrastructure and foreign-language environment that are sufficient to encourage and develop students to be able to speak and write in Islamic English whereas, the main inhibiting factor in Islamic English Learning Process at PM is the attitude of Students who 
categorized the punishment as trivial and normal. There is concern from the headmaster of the Madrassa and teachers that if the punishment is of a physical punishment such as being hit. That will make Students feel resentful towards the instructor or senior who gave the punishment. The existence of punishment for establishing discipline as currently carried out has not had a great impact on Students. They consider all these penalties were normal and trivial.

\section{References}

Almurashi, W. A., Dedi, Gon, S., Rawekar, A., Systems, P., Heritage, O. F., In, L., Sulawesi, S., Watkins, J., Wilkins, M., \& Li, V. (2017). Designing a Syllabus of Collaborative English. International Journal of English Language and Lingusitics Research, 4(1), 19. https://doi.org/10.18311/mvpjms/0/v0/i0/8454

Atiek Mustikawati, D. (2015). Register Bahasa Transportasi(Studi Pemakaian Bahasa Kelompok Profesi). http://eprints.umpo.ac.id/2004/

Clark, J., \& Yallop, C. (2006). An Introduction to Sociolinguistics Blackwell Textbooks in Linguistics. In Religion. https://doi.org/10.1353/lan.2003.0268

Effective Teaching Strategies: Lessons from Research and Practice - Roy Killen - Google Buku. (n.d.). Retrieved October 19, 2019, from https://books.google.co.id/books?id=Y535J63QV1kC\&printsec $=$ frontcover\&hl=id\#v $=$ onepage $\& \mathrm{q} \& \mathrm{f}=$ false

Holmes, J. (1992). An introduction to sociolinguistics. Longman. https://books.google.co.id/books/about/An_Introduction_to_Sociolinguistics.html?id $=$ ouZwAAAAIAAJ\&redir_esc $=y$

Kaharuddin, A. (2019). the Power of English: Recognizing and Utilizing the Tremendous Impact of the English Language on the Community. English Language Teaching for EFL Learners, 1(1), 39. https://doi.org/10.24252/elties.v1i1.7625

Kuiper, M. (n.d.). From Nizamuddin to the Nations: Transnational Trajectories at the Origins of the Tablighi Jama'at. Lord the Air Smells Good: Felicitation Volume in Honour of Paul Jackson. Retrieved October 19, 2019, from https://www.academia.edu/35135605/From_Nizamuddin_to_the_Nations_Transnatio nal_Trajectories_at_the_Origins_of_the_Tablighi_Jama_at

Lindblom, K. (2004). Teaching English in the World. The English Journal, 93(6), 97. https://doi.org/10.2307/4128902

Mahboob, A. (n.d.). Pakistani English. Pakistani English. Retrieved October 19, 2019, from https://www.academia.edu/2654074/Pakistani_English

Mahboob, A. (2009). English as an Islamic language: a case study of Pakistani English. World Englishes, 28(2), 175-189. https://doi.org/10.1111/j.1467-971X.2009.01583.x

Marengo, V. A., Vercelheze, A. E. S., Mali, S., Wang, Y. Y. Y. Y. Y., Liu, J. J., Kang, D., Wu, C., Wu, Y. Y. F., Butterworth, E., Richards, A., Jones, M., Brix, H., Dotro, G., Jefferson, B., Pedescoll, A., Rodríguez, L., Sarañana, A. A., Hijosa-valsero, M., Bécares, E., ... Dantas, T. L. P. (2017). International Journal of Research Publications Volume-14, Issue-1 , October 2018. Water Research. https://doi.org/10.1016/j.chemosphere.2015.11.090

Miji Lestari, P. (2012). The Language of Street Children: A Sociolinguistic Study in the 
Regency of Klaten, Central Java. Register Journal, 5(1), 73. https://doi.org/10.18326/rgt.v5i1.73-100

Putri, E. W., Fauzan, U., \& Toba, R. (2018). The Quality of Listening Skill of the EFL Students. IJELTAL (Indonesian Journal of English Language Teaching and Applied Linguistics). https://doi.org/10.21093/ijeltal.v3i1.125

Rahman, T. (n.d.). The development of English in Pakistan. The Future of English as a Global Language, 13-27. Retrieved October 19, 2019, from https://www.academia.edu/20869545/The_development_of_English_in_Pakistan

Rahman, T. (2008). Language, ideology and power: language-learning among the Muslims of Pakistan and North India. Orient Longman Private Limited. https://www.researchgate.net/publication/271521038_Language_Ideology_and_Pow er_Language_Learning_among_the_Muslims_of_Pakistan_and_North_India

Reetz, D. (n.d.). Living like the Pious Ancestors: The social ideal of the missionary movement of the Tablīghī Jamā'at. DAVO - Annual Conference. Retrieved October 19 , 2019 , from https://www.academia.edu/35019543/Living_like_the_Pious_Ancestors_The_social_ ideal_of_the_missionary_movement_of_the_Tablīghī_Jamā_at

Risdianto, F. (2016). Model Pembelajaran Bahasa Inggris di Ponpes Ta'mirul Islam Surakarta. LEKSEMA: Jurnal Bahasa Dan Sastra. https://doi.org/10.22515/ljbs.v1i1.24

Risdianto, F., Famularsih, S., Rini, S., \& Muthohar, A. (2019, October 8). The use of drama to develop English speaking autonomous learning. https://doi.org/10.4108/eai.27-4-2019.2286844

Rusdiana, J. (2016). Fenomena Dakwah Jamaah Tabligh dalam Perspektif Interaksionisme Simbolik. https://digilib.uns.ac.id/dokumen/detail/52910/FenomenaDakwah-Jamaah-Tabligh-dalam-Perspektif-Interaksionisme-Simbolik

Suharsimi Arikunto. (1992). Prosedur penelitian: suatu pendekatan praktik. Rineka Cipta.

https://books.google.co.id/books?id=aO5BAQAACAAJ\&dq=Arikunto,+Suharsimi.+ (1996).+Prosedur+Penelitian\&hl=en\&sa=X\&ved=0ahUKEwjm3sDa26flAhWDXSs KHWooAuIQ6AEIWzAG

Sungatmi, S. (2019). Implementasi Model Inquiry Learning Untuk Meningkatkan Hasil Belajar Kd Mengidentifikasi Cara Makhluk Hidup Menyesuaikan Diri Dengan Lingkungan Tema Persatuan Dalam Perbedaan Siswa Kelas VI Semester 1 SDN 01 Karanganyar Tahun Ajaran 2018/2019. Jurnal Pendidikan Indonesia, 4(7). https://jurnal.fkip.uns.ac.id/index.php/jpi/article/view/12471

Widodo, H. P. (2018). Situating Moral and Cultural Values in ELT Materials: The Southeast Asian Context. English Language Education, 9, 131-152. https://doi.org/10.1007/978-3-319-63677-1 